I address you, two thousand unfortunate beings tied in strait-jackets; and the total number of insane on the continent confined in cells, fastened in beds, and strapped up in strait-jackets, amounts in 1867 to fifty thousand. It is for me, as a foreigner, a humiliation, and perhaps at the same time a proof of my professional courage, that I denounce these facts before so high an authority as yourself, and on so solemn an occasion as this of to-day. But my aim is only to impress on you the importance of your continuing to censure this barbarous practice; the more so, as your countrymen, induced by the man whose bust now stands before you, have proved that lunatics can be successfully treated otherwise; and thus you have conferred the greatest benefit on the unhappiest part of our fellow-creatures. "The monument which, after my death, I wish to be erected for me on the continent is the practice of non-restraint ; and may this soon be a reality!" These words I frequently heard from the lips of a man to whom you so often listened with delight in this same room, and whose marble effigy we have now to beg you to accept and place here in perpetual remembrance of him.

Sir Thomas Watson, in reply, pronounced a touching and graceful eulogium upun the late Dr. Conolly in the following words :-

Baron Mundy and Dr. Tuke.-The Fellows of the College of Physicians, here in full Comitia assembled, authorise me, their President, to express to you, in their name and my own, our gratification and gratitude for the privilege which we owe to your concurrent liberality of possessing and of placing permanently within our walls the marble bust of one of our body, whose death we, like you, have but recently been deploring, and whose memory we, like you, desire to cherish and perpetuate-the late Dr. John Conolly. To you, Baron Mundy, we offer the tribute of our respect and admiration for your munificence in procuring so costly and graceful a memorial of your and our departed friend. And to you, Dr. Tuke, and to the Society represented by you - the Medico-Psychological Association, to whom the bust was in the first instance presented by Baron Mundy, - we have to tender our grateful acknowledgment for the honour you have done this College by resigning it into our keeping. And again, thanks are due from us to the Baron for his gracious and ready consent to that transference. Our sculptured treasures, gentlemen, are not numerous, but they are tolerably select. I do not scruple to say that the bust of Conolly is not unworthy of being associated here with those of Sydenbam, of Mead, of Harvey, and, coming to men of his own time, of Mat thew Baillie, of Halford, of William Babington. Like theirs, or some of theirs, his name will go down to a remote posterity, and be reckoned among those of the greatest and most noble benefactors to a very suffering portion of the human race that our pro. fession and our country have ever produced.

\title{
Dr. Maudsley on the Physiology and Pathology of the Mind.*
}

Dr. Maudsley has had the courage to undertake, and the skill to execute, what is, at least in English, an original enterprise. His book is a manual of mental science in all its parts, embracing all that is known in the existing state of physiology. There have indeed been more than one attempt to include something of physiological observation in the investigation of mental phenomena. Dr. Abercrombie, Professor Bain, and Mr. Herbert Spencer must have the credit which is due to those who have led the way in giving this

* 'The Physiology and Pathology of the Mind.' By Henry Maudsley, M.D. London: Macmillan and Co., 1867. 
direction to mental science. The revolution, for it is nothing less, which has taken place in this branch of knowledge was begun by the psychologists themselves. But it required a professional pliysiologist to grasp all the phenomena of the nervous system, its normal and abnormal conditions, in one view, and to treat them exclusively on the basis of observed facts. Many and valuable books have been written by English physicians on insanity, idiocy, and all the forms of mental aberration. But derangement had always been treated as a distinct subject, and therefore empirically. That the phenomena of sound and of unsound mind are not matters of distinct investigation, but inseparable parts of one and the same inquiry, seems a truism as soon as stated. But, strange to say, they had always been pursued separately, and been in the hands of two distinct classes of investigators. The logicians and metaphysicians occasionally borrowed a stray fact from the abundant cases compiled by the medical authorities; but the physician, on the other hand, had no theoretical clue to his observations beyond a smattering of dogniatic psychology learnt at college. To effect a reconciliation between the physiology and the pathology of mind, or rather to construct a basis for both in a common science, is the aim of Dr. Maudsley's book.

Such a book cannot, however, offer itself as complete or final. In the present state of nervous physiology, though enough has been ascertained to enable the main lines of mental science to be laid down, there is still much that is obscure and uncertain. We have not as yet any satisfactory knowledge of the functions of the different parts of the cerebral convolutions. The anatomists cannot even agree on any convolution as peculiar to man all that they can surely say is, that his convolutions are more complex and less symmetrical than those of the monkey. Dr. Maudsley's caution is not the least of his merits; he will not advance beyond ascertained facts, how. ever tempting the theory may seem. The attempts to assign language to the third frontal convolution of the left hemisphere of the brain he will not adopt, because the observations reported are unsatisfactory, and directly contradictory observations are overlooked.

For the old method of psychology, by the interrogation of consciousness, Dr. Maudsley entertains the same feeling as Bacon did for the physics of the Aristotelian schools. Metaphysics have indeed been long sinking into merited contempt. They are cultivated only by those who are engaged, not in action, wherein the true balance of life is maintained, but in dreaming in professorial chairs. An ambitious youth here and there goes through an attack of metaphysics, as a child goes through an attack of measles, and procures thereby an immunity from a similar disease for the rest of his life. And there are dabblers in metaphysics who remain youths for life. By the rest of mankind, whether men of the world or men of science, metaphysics are as little regarded as scholastic theology. Dr. Maudsley not only condemns metaphysics, but renounces that empirical psychology which attained so much renown in the last century, and was the foundation of so many reputations from Descartes to Sir William Hamilton. He regrets that $\mathbf{M r}$. J.S. Mill should have committed himself to the psychological method, and exhibited so much zeal on so desperately forlorn a hope. He wonders that one who has done so much to expound the system of Comte should on this one question take leave of it entirely, and follow and laud a method of research which is directly opposed to the method of positive science. Self-consciousness Dr. Maudsley sets aside as incompetent to supply the facts for building up a truly inductive psychology. Consciousness is not reliable even in that of which it does give information. Descartes laid it down as the fundamental proposition of philosophy, that whatever the mind could clearly and distinctly conceive was true. Yet, if there is one thing more clearly and distinctly 
conceived than another, it is the madman's delusion. Further, the revelations of consciousness reach only to conscious states. But mind and consciousness are very far from coextensive. Even Leibnitz was aware of the existence of what he called "obscure perceptions," i.e. affections of the mind, which, betraying their reality in their effects, are themselves out of apperception. Consciousness can give no account of the material conditions which underlie every mental manifestation, or of those conditions of body to which so large a portion of our mental changes are wholly or in part to be referred.

To give mental science its proper place among the positive sciences, it must be based, as they are, on the study of external nature. The external phenomena from which the laws of mind must be inductively drawn may be classed as - 1. The physiology of the nervous system. 2. The facts of the degeneration of mind, as exhibited in the different forms of idiocy and insanity. 3. The course of development of mind as exhibited in the suc. cessive stages of the infant, the animal, and the barbarian. 4 . The progress or regress of the human mind as exhibited in history. Our object should be to interest the mind in the realities which surround us, and to bring the mind into harmony with the laws of nature. The mind that is in intimate sym. pathy with the course of everts is strong with the strength of nature, and is developed by its force. Power is acquired by the habit of submitting the understanding to things. Natural gifts sharpened by mere logical training are not enough without a large experience of life and men.

The very first thing necessary for the student of mental science is to form a just conception of what is meant by mind. The metaphysical conception of it as a peculiar entity, the laws of which can be known in a way peculiar to themselves, must be discarded. Upon this abstraction, an imaginary substance, the supposed source of power and self-sufficient cause of causes, . have been built all the endless and contradictory systems of philosophy. On the other hand, the crude proposition of Cabanis, that the brain secretes thought as the liver secretes bile, is not a true expression of the facts. Mind may best be described as a natural force or energy manifested to us only through certain changes in matter. As there are different kinds of matter, so there are different modes of force in the universe. We rise from mere physical matter, in which physical laws hold sway, up to chemical matter and chemical forces, and from chemical matter again up to living matter; so we rise in the scale of life from the lowest kind of living matter up to the highest kind with which we are acquainted-namely, nerve tissue, with its corresponding nerve force. The highest development of force is necessarily the most dependent, as to its existence all the lower natural forces are indispensably requisite. All exaltation of force is a concentration of it. As one equivalent of chemical force corresponds to several equivalents of inferior force, and one equivalent of vital force to several equivalents of chemical force, so in the scale of tissues the higher kind represents a more complex constitution and a greater number of simultaneously acting forces than the kind of tissue below it in dignity. The highest energy in nature implicitly contains all the lower kinds of energy. The idea of organization is therefore necessary to the interpretation of every manifestation of life. The mind implies a plastic power ministering to a complex process of organization during which what is suited to development is assimilated, what is unsuitable is rejected. Looking at man as a small and subordinate part of a vast and harmonious whole, the history of mankind is the history of the latest organic development of nature. In the evolution of the human mind nature is undergoing its consummate development. The law of this development is the law of progressive specialization and increasing complexity.

As with the term "mind," so with that of "idea." It has been converted by the metaphysicians into an entity. A general term, summing up a great 
number of varied phenomena, has been supposed to denote an object having uniform and constant properties. The so-called fundamental ideas or categories of the understanding, which make so large a figure in systems, have by no means a permanent value, quantitative or qualitative. They have no absolute truth as expressions of certain fundamental relations between man and nature. The formation of an idea is an organic evolution in the appropriate nervous centres, a development which is gradually completed in consequence of successive experiences of a like kind. The cells of the cerebral ganglia idealize the sensory perceptions; grasping that which is essential in them, and suppressing or rejecting the unessential, they mould them by their plastic faculty into the organic unity of an idea.

In treating the emotions, it would appear that little new light is to be gained from physiological observation. We are compelled to assume a delicate organization of the nervous structure on which emotion depends, though by reason of the imperfection of our means of investigation, we are not yet able to trace a process of such delicacy in those inmost recesses to which our senses have as yet not gained access. Meanwhile "Spinoza's admiruble account of the passions, which has never yet been surpassed, and certainly will not easily be surpassed," may be adopted-a concession to the old psychology for which we were hardly prepared after the denunciations of it with which the author commenced. The general relation of emotions to ideas, which they equal in number and variety, and the building up of character by the association of emotions, pleasurable or painful, with given thoughts, is precisely the same as has been long given by the established psychology.

We come next to volition. Here we are again cautioned to dismiss from our minds the metaphysical conception of will as a fixed and undecomposable entity of uniform power. Under the category of voluntary acts are really included very various kinds of actions proceeding from different nervous centres. There is no such thing as an ideal will, unaffected by physical conditions, existing apart from particular concrete voluntary acts. What we call will is the final reaction after deliberation, and, like other modes of reaction of nerve element, is a resultant of molecular change in some one nervous centre. It is true that each act of will contains a conception of the end desired; this conception of the result, or design, constituting the essential character of the particular volition. But the design itself is a physical necessity, being a consequence of cerebral adaptation to the varieties of external impression. So far from the design manifest in a mental act evincing a power which transcends or anticipates experience, it is one which conforms entirely to experience. The more cultivated the mind and the more varied the experience, the better developed is the will, and the stronger its coordinating power over the thoughts, feelings, and actions. The will is no despot; it is ever most obedient where it has most power; it conquers by obeying. The history of a man is the revelation of his character. What he has done indicates what he has willed. What he has willed marks what he has thought and felt; and what he has thought and felt has been the result of his nature as the developed product of an original constitution plus a life experience. The will is the highest force in nature, the last consummate blossom of all her marvellous efforts. It represents the exquisitely adapted reaction of man to the best insight into the relations in which he moves. It is by the power of a well-fashioned will that a man reacts with intelligent success upon the external world, brings himself into complete harmony with his surroundings, assimilates and incorporates nature, and thus carries forward its organic evolution.

Neither in the chapter on volition, nor in that on memory, will any details be found which differ from what is usually delivered under those heads in the 
standard treatises of mental philosophy. The merit of Dr. Maudsley's work does not lie in its parts, but in the grouping of the whole, and the reference of each department to a few proper principles-the substitution, in fact, of known physiological laws for the arbitrary dicts of so-called consciousness. This is true not only of the first part of the volume, which treats of the normal development of mind, but also of the second half, in which the subject is degeneration of mind. Indeed so much has been written on insanity that what is wanted here is arrangement rather than fresh observation, and the application of ascertained principles of biology. Facts and cases have been accumulated in enormous numbers, and have outgrown theory; or rather theories have not been wanting, but they have been basty, partial, empirical. What has been had in view has naturally been treatment of patients. While curative treatment has been slowly advancing to perfection, theory has been left to take its chance.

In saying that curative treatment of the insane is carried to perfection, it will of course be understood that the system, and not the practice, is intended. The principles of treatment are well understood by the medical profession, but special difficulties exist in the way of bringing the knowledge thus possessed to bear on the patient in this class of disorders which do not exist in other branches of practice. These difficulties consist chiefly in the fact that the insane patient cannot be treated, like other patients, in his own home, but must, it is thought, be removed to an institution. Great indeed has been the improvement in the management of asylums in this country since Tuke directed attention to the barbarities of the old s7stem. But these institutions, generally speaking, are still far from being all that could be wished, or what they might be made. Laws hastily passed under the influence of popular panic and newspaper philanthropy thwart the medical officer at every step. The country is covered with overgrown and overcrowded asylums, into which the whole lunatic population is densely packed, so as to defy classification. The timely treatment of the early stages of the disease is rendered impossible. Our lunacy legislation is but one of the many costly failures of Parliamentary Government. The preposterous attempt of a miscellaneous assemblaye of $\mathbf{6 5 8}$ gentlemen to make regulations for any thing and everything is here, as in 80 many other departments of the public service, a fruitful cause of confusion, and obstacle to improvement. Dr. Maudsley is an adrocate for private treatment, where possible. On the same principle on which we have gone great lengths in abolishing restraint within asylums, le contends that we should go on to abolish the restraint of asylums in the many cases to which such treatment is applicable. He quotes the report of the Scottish Commissioners in Lunacy on the condition of the pauper insane in private dwellings in Scotland. A few years ago these poor creatures were in a wretched condition, either of neglect or ill-usage. Now all is changed. By the agency of official instruction and inspection, sys. tematically exercised, all who have to do with them have been penetrated with more enlightened views. The condition of their charges now leaves little to be desired. The former evils sprang not so much out of deliberate cruelty, as out of want of knowledge on the part of those who had concern in them.

We have not space to follow, even in outline, Dr. Maudsley's arrangement of the pathology of mind. It is a most judicious summary of well-established principles, illustrated without being overloaded by cases. The essay on the Causes of Insanity (part ii, c. l) has an interest far beyond professional circles or philosophical students. It is a moral study, containing practical truths of most serious import to all who live within the vortex of the social influences of modern civilization. A steady increase in the number of cases of insanity an increase which for England and Wales alone is at the rate of one thousand 
a year, is far more than proportionate to the general increase of population, and is not sufficiently accounted for by the fact that more people are now declared mad than used to be so formerly. Dr. Maudsley proceeds, in pages (200-258) marked by cautious statement and the stamp of a wide experience, to trace the causes of this increase to the varied excitements of English life. We should like to see the whole of the chapter "On the Causes of Insanity" reprinted by itself in a cheap form for wider circulation.-The Saturday Review, May 25th.

\section{Was Luther Mad?}

Ix the recent trial, in which the validity of the will of Mrs.jThwaites was disputed, because of the extreme religious delusions which she was proved to have had for many years, Mr. Serjeant Ballantine elicited from Dr. Williams

- Religious Hallucinations.-Whatever be the issue of the singular will case which has been occupying the attention of the Court of Probate for so many days, it may possibly contribute some little towards the settlement of the unsatisfactory state of English law as to the condition of mind which constitutes what is termed " testamentary incapacity." The arguments against the validity of Mrs. Thwaites's will raise, in fact, one of the most difficult psychological and social problems that can be imagined. Did the religious hallucinations under which she laboured con. stitute real legal insanity? And if she was really insane, is there any truth in the theory of one of the doctors who were examined, who held that a person may be mad on religious subjects, and yet perfectly sane upon all others? There is also a still further question involved. Onght all insanity, as such, necessarily to incapacitate a person from disposing of his property by will? And then there is the practical question, what constitutes a religious hallucination so entirely a delusion that it may be held to be the product of a disordered mind, and yet at the same time be compatible with practical sanity on all secular matters? Or, to state the difficulty from another point of view, is it possible to be mad on religious topics without suffering from disease of the brain, either organic or functional? To answer these questions, even in the most hesitating way, would be, of course, impossible in the space of a paragraph. But it may be useful to suggest one or two of the difficulties which surround the subject, from whichever point of it is approached. Insanity, says modern pathology, is a disease of the brain ; but in many cases how do we know that the brain really is diseased, except from the occurrence of certain mental phenomena, which may, after all, be the result of mere defective processess of reasoning, having no connection whatever with physical disease? In such cases we are driven to argue in a circle. Such and such a man is not responsible for his actions, and is incapable of making a legal will, because his brain is disordered. But how do we know his brain is disordered? Because his acts are inconsistent with the laws of reasoning. But is everybody who cannot reason to be held legally insane? No; only when the brain is diseased. But how do wo know this in the one case before us? and so on, round and round without end. The truth is that, especially in religious subjects, we have often no recognised tests as to what constitutes insanity. For instance, supposing that a will was found to contain a clause for providing a proper personal reception in the way of house, attendants, and ceremonial for the Founder of Christianity on his appearing in London on such and such a date, would any jury hesitate to hold this provision a conclusive proof of the testator's madness ? Yet how would this provision differ from the practice of the Irvingite body, who at one time made preparations in their churches for the possible appearance of Jesus Christ among them? They may do it still, for all we know. They certainly practised the "speaking in unknown tongues," under the belief of being personal instruments of the Holy Ghost, until very recently.-Pall Mall Gazette. 